\title{
THE CRYSTALLiZATION PRESSURE OF ICE-A SIMPLE EXPERIMENT
}

\author{
By D. C. ConnelL* and J. M. C. Tombs $\dagger$ \\ (H. H. Wills Physics Laboratory, University of Bristol, Bristol, England)
}

\begin{abstract}
Polycrystalline ice, growing from the melt, can exert a pressure against an extended obstacle, even though it is free to grow in other directions. Pressures of over 0.2 bar $\left(20 \mathrm{k} \mathrm{V} \mathrm{m}^{-2}\right)$ have been measured with simple apparatus. This phenomenon may be important in explaining the frost-shattering of rocks.

RÉsumé. La pression de cristallisation de la glace-une expérimentation simple. De la glace polycristalline, croissant à partir de glace fondue, peut exercer une pression contre un obstacle étendu, même si elle est libre de croître dans les autres directions. Des pressions de plus de 0.2 bar $\left(20 \mathrm{kN} \mathrm{m}^{-2}\right)$ par $\mathrm{cm}_{\text {ont }}$ été mesurées avec un appareillage simple. Ce phénomène peut être important pour expliquer la gélifraction des roches.

Zusammenfassung. Der Kristallisationsdruck von Eis-ein einfacher Versuch. Polykristallines Eis, das aus der Schmelze wächst, kann Druck gegen ein ausgedehntes Hindernis ausüben, auch wenn es ungehindert in andere Richtungen wachsen kann. Drucke von über 0.2 bar $\left(20 \mathrm{kNm}^{-2}\right)$ werden mit einem einfachen $\mathrm{Gerät}$ gemessen. Dieses Phänomen kann für die Erklärung der Frost-sprengung von Felsgestein bedeutungsvoll sein.
\end{abstract}

THE phenomenon of frost-heaving in porous granular materials has been explained by Everett (196I) as a consequence of water freezing in a system of pores of different sizes with interconnecting capillaries. It arises not from the expansion of water when it freezes but from a surface-energy effect: the pressure difference that exists across a curved ice-water interface. It is of interest to determine whether a similar mechanism could be involved in the wedging action of frost in cracks in non-porous rocks, often attributed simply to the expansion of water on freezing. The shattering of rocks by this process (and by the analogous process of salt deposition in cracks) is generally regarded as an important factor in the erosion of certain major landforms.

The existence of a pressure exerted on obstacles by a growing crystal has been recognized at least since the beginning of the century, but very little quantitative work has been done, and it has been concerned mainly with growth from solution rather than from the melt. Scheil (1935) found a value of $5 \mathrm{~kg} \mathrm{~cm}^{-2}\left(500 \mathrm{kN} \mathrm{m}^{-2}\right)$ for $\mathrm{Zn}$; we believe this is the only measurement involving growth from the melt. Correns and Steinborn (1939) grew single crystals of alum from aqueous solution between horizontal plates of glass or mica, and measured the crystallization pressure tending to force the plates apart by means of a balance and optical-lever system. With glass plates, pressures of up to $50 \mathrm{~kg} \mathrm{~cm}^{-2}$ $\left(5000 \mathrm{kN} \mathrm{m}^{-2}\right.$ ) were recorded, increasing with supersaturation, but with mica plates the pressure was always zero.

A critical discussion of the available experimental data, together with a theoretical analysis of the problem, has been given by Khaimov-Mal'kov ( 959 [a], [b]). He concludes that the crystallization pressure theoretically available can be quite large and, for growth from the melt, is a function of supercooling, which is often linear for small supercoolings. For growth from solution "the important parameter is supersaturation". However, the pressure realized in practice by its ability to do work may be severely limited by the supply of new material to the growth face in contact with the (large) obstacle. (The same difficulty must arise in the system discussed by Everett (196r).) We may add that when ice grows from the melt, one possible route for the addition of material at the interface would be a very thin film of water, or "quasi-water", at the surface of the ice. Jellinek ( 1967$)$ reviews ideas on such a film, and a theoretical discussion is given by Fletcher (1962, 1963).

In the present experiment, polycrystalline ice was grown from the melt between glass plates, but the pressure was measured by a method somewhat simpler than that of Correns and Steinborn. A glass trough (Fig. I) was filled to a depth of about $\mathrm{I} \mathrm{cm}$ with tap water and a jet of cold air A was played on to the bottom of the trough, causing the growth of a shallow dome $\mathrm{I}$ of polycrystalline ice. About $1.5 \mathrm{~mm}$ above the bottom of the trough and parallel to it was a glass slide s, supported at one end by two pins $\mathrm{P}$ and at the other by a small piece of glass with a convex top surface c. This was illuminated

* Present address: Operational Research Department, British Iron and Steel Research Association, I40 Battersea Park Road, London, S.W.i i, England.

† Present address: Institute of Geological Sciences, 5 Princes Gate, London, S.W.7, England. 
with sodium light, as shown, and the Newton's rings produced near the point of contact were viewed by reflection through a low-power microscope; an inwards movement of the rings indicated when the slide was being lifted and the total movement could be determined by counting the fringes disappearing at the centre. The ice dome was illuminated with white light by a similar optical arrangement (not shown in the figure) and observed through a hand lens. The slide was loaded by placing weights $\mathrm{w}$ directly on it. The ice was allowed to grow until it just touched the slide (Fig. 2) and, where it did so, irregular bright patches could be seen. It was observed that, after initial contact, the bright area grew and became roughly circular (Fig. 3), until after some further time the slide quite suddenly began to lift.

The area of contact between ice and glass had a complex appearance. Under a low-power microscope individual ice crystals could be seen forming, releasing bubbles of air from solution. At the time of the experiment, it was believed that the bright patches represented ice-glass contact, but more recent work by Mrs M. Branson (personal communication) has shown that the bright areas in Figure 3 are due to a layer of air, whilst the dark patches in between, and extending out to the quite well-defined circle on which the radial bubbles end, represent the true ice-glass contact. In consequence, the exact area over which the force was exerted cannot now be determined; if it is the whole area, out to the ring where the radial bubbles end, this corresponds to a maximum pressure of over 0.2 bar $\left(20 \mathrm{kN} \mathrm{m}^{-2}\right)$. The maximum upward growth of the ice against the constant applied load was $0.1 \mathrm{~mm}$ (the ice dome was about I. $4 \mathrm{~mm}$ thick). The observed pressure varied considerably from one experiment to another, but large growths were associated with small loads and small areas of contact.

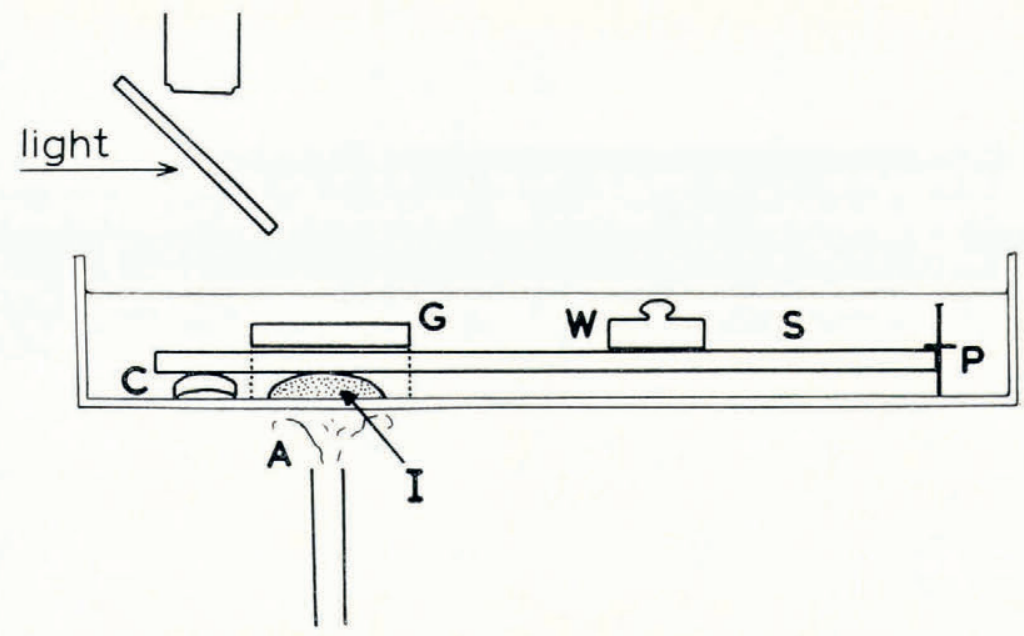

Fig. I. The crystallization pressure apparatus.

It is useful to consider briefly some possible mechanisms for the process. If a mechanism similar to Everett's were responsible, we can calculate the radius of the capillary that would give the observed pressure by the simple relation:

$$
\Delta P=\sigma\left(\frac{\mathrm{I}}{r_{1}}+\frac{\mathrm{I}}{r_{2}}\right)=\frac{2 \sigma}{r_{\mathrm{m}}},
$$

where $\Delta P$ is the excess pressure, $\sigma$ is the interfacial tension at the ice/water interface, $r_{1}$ and $r_{2}$ are the two principal radii of curvature, and $r_{\mathrm{m}}^{-1}$ is the mean curvature. With $\sigma=33$ dyne $\mathrm{cm}^{-1}\left(0.033 \mathrm{~N} \mathrm{~m}^{-1}\right)$ (Hobbs and Ketcham, I 969 ), a pressure of 0.2 bar $\left(20 \mathrm{kN} \mathrm{m}^{-2}\right.$ ) would be given by a capillary of radius $r_{\mathrm{m}}=3 \mu \mathrm{m}$. This is much smaller than the radii of curvature associated with the overall shape of the ice specimens used in our experiments - for the separation of the glass plates was $1.4 \mathrm{~mm}$ and the radius of the ice dome in the horizontal plane was typically $3 \mathrm{~mm}$. Clearly, such large radii cannot account for the observed pressures. Radii in the micrometre range may, however, occur in the complicated interfacial pore system in the region of contact close to the glass slide.

A second possible explanation of the phenomenon is that small pockets of liquid water may have been trapped by ice, subsequently causing growth by expansion on freezing. But the growths of up to. 


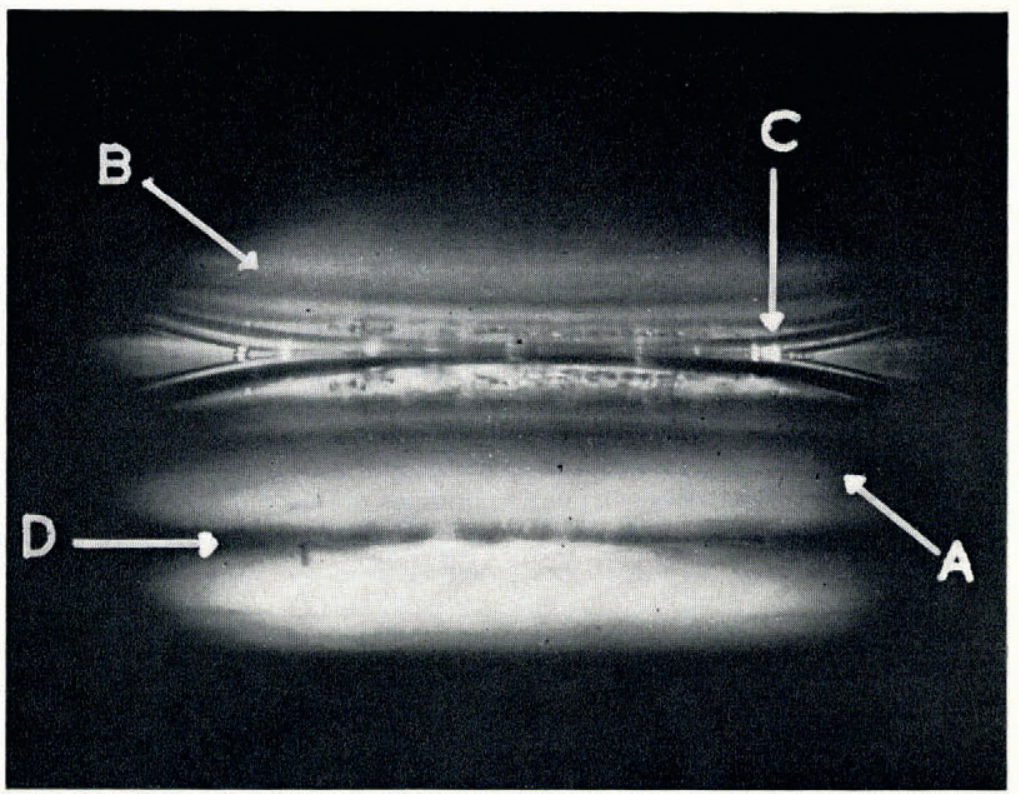

Fig. 2. Side view of the ice dome $A$, growing between glass plates. There is also a reflection $B$ of the ice in the top plate. Note the smoothness of the ice surface and air bubbles $C$ in the region of contact. The base of the ice is at $D$.

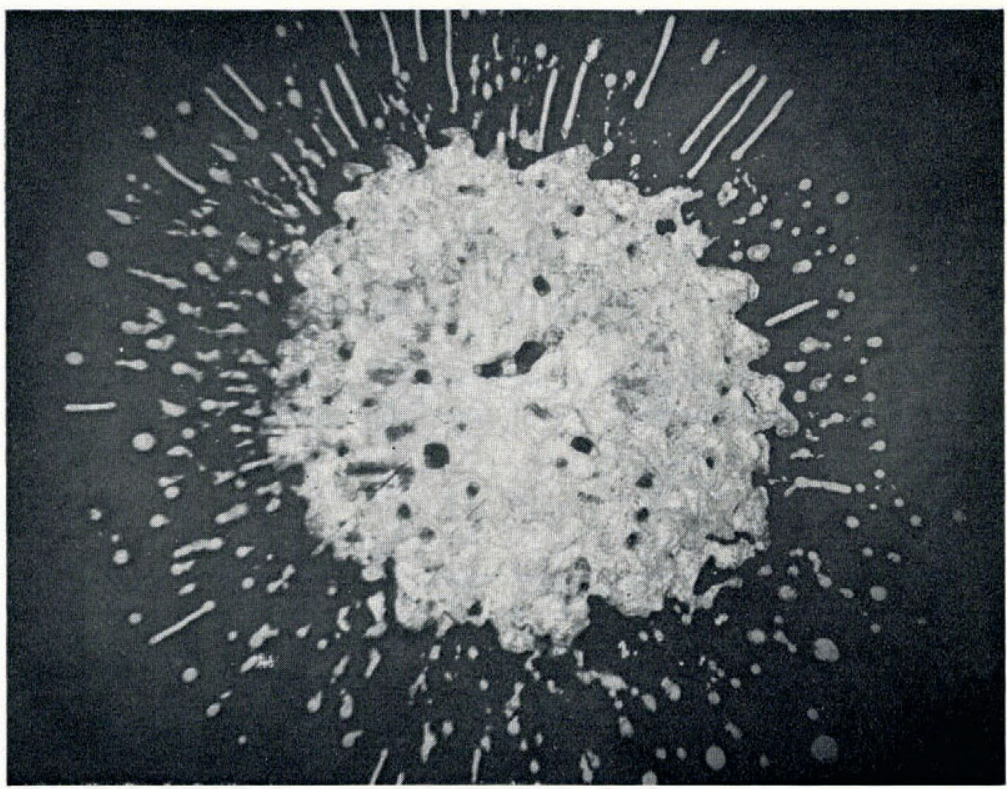

Fig. 3. Appearance of the ice dome in contact with glass slide as viewed from above. Diameter of bright central region approximately $8 \mathrm{~mm}$. 
$0.1 \mathrm{~mm}$ which were observed would require the equivalent of the unidirectional freezing of a $\mathrm{I} \mathrm{mm}$ column of water if no new material were added from outside. It seems unlikely, therefore, that this can be a complete explanation.

The remaining mechanism is that of crystallization pressure itself. The values may appear rather low in comparison with those of Correns and Steinborn, but the limiting factor is the supply of new material over the whole area of contact, as suggested by Khaimov-Mal'kov. We cannot at this stage be more definite about the processes involved, but the fact that a pressure was measured at all suggests a number of possible consequences in nature. The experiment was planned as part of an investigation into the mechanism of frost-cracking in rocks. The pressures measured might at first be thought rather small to be effective, but it is to be remembered that some cracks in rocks already lie along planes of weakness. Moreover, although large pressures were only observed for small loads, no upper limit was found for the total force developed. An important factor is the supply of new material to the growth face and this would be facilitated if there were some degree of natural porosity. The process might also be considerably more effective with slower rates of cooling, and in the presence of a rough rock surface rather than a smooth glass one, allowing the formation of a number of small ice domes. It is possible that the crystallization pressure observed in these experiments also has biological implications, in helping to explain tissue damage caused by freezing.

This work was originally undertaken as a third-year undergraduate project at the $\mathrm{H}$. $\mathrm{H}$. Wills Physics Laboratory, Bristol, under the supervision of Professor J. F. Nye, to whom we are indebted for suggesting the project, for his constant support and encouragement and for his guidance in preparing this report. Further research into the phenomenon is continuing at Bristol.

MS. received 3 December 1970

\section{REFERENCES}

Correns, C. W., and Steinborn, W. 1939. Experimente zür Messung und Erklärung der sogenannten Kristallisationskraft. Zeitschrift für Kristallographie, Mineralogie, und Petrographie, Abt. A, Bd. Io I, Ht. I-2, p. I I 7-33.

Everett, D. H. 1961. The thermodynamics of frost damage to porous solids. Transactions of the Faraday Society, Vol. 57 , No. 465, Pt. 9, p. 1541-51.

Fletcher, N. H. 1962. Surface structure of water and ice. Philosophical Magazine, Eighth Ser., Vol. 7, No. 74, p. $255-69$.

Fletcher, N. H. 1963. Surface structure of water and ice- a reply and a correction. Philosophical Magazine, Eighth Ser., Vol. 8, No. 92, p. $14^{25}-26$.

Hobbs, P. V., and Ketcham, W. M. 1969. The planar growth of ice from the pure melt. (In Riehl, N., and others, ed. Physics of ice: proceedings of the international symposium on physics of ice, Munich, Germany, September 9-14, I968. Edited by N. Riehl, B. Bullemer, H. Engelhardt. New York, Plenum Press, p. 95-1 12.)

Jellinek, H. H. G. 1967. Liquid-like (transition) layer on ice. Fournal of Colloid and Interface Science, Vol. 25, No. 2, p. $192-205$.

Khaimov-Mal'kov, V. Ya. 1959[a]. K termodinamike kristallizatsionnogo davleniya [The thermodynamics of crystallization pressure]. (In Shubnikov, A. V., and Sheftal', N. N., ed. Rost kristallov. Tom 2. Moscow, Izdatel'stvo Akademii Nauk SSSR, Institut Kristallografii, p. 5-16.) [English translation: Growth of crystals. Vol. 2. New York, Consultants Bureau, 1959, p. 3-13.]

Khaimov-Mal'kov, V. Ya. 1959[b]. K voprosy eksperimental'nogo opredeleniya velichiny kristallizatsionnogo davleniya [Experimental measurement of crystallization pressure]. (In Shubnikov, A. V., and Sheftal', N. N., ed. Rost kristallov. Tom 2. Moscow, Izdatel'stvo Akademii Nauk SSSR, Institut Kristallografii, p. 17-25.) [English translation: Growth of crystals. Vol. 2. New York, Consultants Bureau, 1959, p. 14-19.]

Scheil, E. 1935. Über das Auftreten einer hohen Kristallisationskraft bei der Bildung von Eisen-ZinkLegierungen. Zeitschrift für Metallkunde, 27. Jahrg., Ht. 4, p. 76-77. 